\title{
KEDUDUKAN KORBAN KEJAHATAN DALAM SISTEM PERADILAN PIDANA DI INDONESIA BERDASARKAN KITAB UNDANG-UNDANG HUKUM ACARA PIDANA (KUHAP)
}

\author{
Ni Putu Rai Yuliartini \\ Jurusan Ilmu Hukum \\ Universitas Pendidikan Ganesha \\ E-mail : ray_gex@yahoo.com
}

\begin{abstract}
ABSTRAK
Penelitian ini bertujuan untuk menganalisis bagaimana kedudukan korban kejahatan dalam sistem peradilan pidana di Indonesia. Metode penelitian yang digunakan dalam penulisan karya ilmiah ini adalah penelitian hukum normatif, dengan menggunakan pendekatan undang-undang (act approach). Hasil penelitian menunjukkan bahwa sistem peradilan pidana di Indonesia berdasarkan Kitab Undang-Undang Hukum Pidana (KUHAP) terlalu difokuskan pada pelaku dan kurang memperhatikan korban. Hal ini dapat dilihat pada minimnya pengaturan yang terdapat dalam KUHAP yang membahas tentang eksistensi korban kejahatan. Dengan demikian posisi korban kejahatan di sini hanyalah sebagai saksi dari suatu perkara pidana yang semata-mata untuk membuktikan kesalahan tersangka/terdakwa. Padahal masalah keadilan dan penghormatan Hak Asasi Manusia tidak hanya berlaku terhadap pelaku kejahatan saja, tetapi juga korban kejahatan.
\end{abstract}

Kata Kunci : Korban kejahatan, Sistem Peradilan Pidana, KUHAP

\section{ABSTRACT}

This research aims to analyze how the victims position in Indonesian criminal justice system. Method used in this paper is a normative legal research, by using the statute approach. The results showed that the criminal justice system in Indonesia based on the Code of Criminal Law (Criminal Code/ KUHAP) is too focused on the actors and less attention to the victims. This can be seen in the lack of regulation contained in the Criminal Code which deals with the existence of victims of crime. Thus the position of victims only as a witness of a criminal case that solely to prove the guilt of the suspect/ defendant. Though the issue of justice and respect for human rights does not only apply to offenders but also victims of crime.

Keywords: Victims of crime, Criminal Justice System, Criminal Code/ KUHAP

\section{Pendahuluan}

Hukum pidana sudah seharusnya mampu melindungi Hak Asasi Manusia baik pelaku maupun korban kejahatan serta melindungi kepentingan-kepentingan masyarakat dan negara dengan perimbangan yang serasi. Namun hal tersebut tidak seluruhnya sesuai dengan kenyataan, permasalahan itu terjadi karena berbagai faktor diantaranya adalah secara 
substansial Undang-undang No. 8 Tahun 1981 tentang Kitab Undangundang Hukum Acara Pidana (KUHAP) tidak memberikan perlindungan yang baik/memadai terhadap korban kejahatan.

Kelemahan mendasar dalam penegakan hukum pidana dimaksud adalah terabaikannya hak korban kejahatan dalam proses penanganan perkara pidana maupun akibat yang harus ditanggung oleh korban kejahatan. Hal ini dapat dilihat dalam KUHAP, sedikit sekali pasalpasal yang membahas tentang korban, pembahasannya pun tidak fokus terhadap eksistensi korban tindak pidana. Terlihat dengan bermacam-macamnya istilah yang digunakan dalam menunjuk seorang korban.

Korban kejahatan yang pada dasarnya merupakan pihak yang paling menderita dalam suatu tindak pidana, justru tidak memperoleh perlindungan sebanyak yang diberikan oleh undang-undang kepada pelaku kejahatan. Akibatnya, pada saat pelaku kejahatan telah dijatuhi sanksi pidana oleh pengadilan, kondisi korban kejahatan seperti tidak dipedulikan sama sekali. Padahal masalah keadilan dan penghormatan Hak Asasi Manusia tidak hanya berlaku terhadap pelaku kejahatan saja, tetapi juga korban kejahatan.

Menurut Pasal 27 ayat (1) Undang-Undang Dasar NRI 1945, yang menyatakan, bahwa "Segala warga negara bersamaan kedudukannya di dalam hukum dan pemerintahan dan wajib menjunjung hukum dan pemerintahan itu dengan tidak ada kecualinya." Dalam hal ini Negara berkomitmen bahwa setiap warga negara harus diperlakukan adil sama kedudukannya di dalam hukum, juga dalam pengertian apakah ia seorang tersangka atau korban suatu tindak pidana, perikemanusiaan sebagai sendi nilai falsafah negara Pancasila menjiwai seluruh keberadaan hukum di Indonesia, mulai dari UUD RI 1945 hingga peraturan perundangundangan dibawahnya.

Sistem peradilan pidana melalui produk peraturan perundang-undangan Indonesia, khususnya Kitab Undang-Undang Hukum Acara Pidana (KUHAP) yang menjadi dasar dari penyelenggaraan sistem peradilan pidana, yang belum benar-benar mencantumkan terhadap apa yang di isyaratkan dalam UUD RI 1945. Hal demikian memunculkan persoalan klasik, bahwa sistem peradilan pidana sebagai basis penyelesaian perkara pidana tidak mengakui eksistensi korban tindak pidana selaku pencari keadilan, seorang korban tindak pidana akan menderita kembali sebagai akibat dari sistem hukum itu sendiri, karena korban tindak pidana tidak bisa dilibatkan secara aktif seperti halnya dalam beracara perdata, tidak dapat langsung mengajukan sendiri perkara pidana ke pengadilan melainkan harus melalui instansi yang di tunjuk (kepolisian dan kejaksaan) (Mudzakir, 2001 : 1).

Pengertian korban kejahatan tidak hanya sebagai orang yang menderita kerugian sebagai akibat terjadinya suatu kejahatan, karena korban kejahatan terkait dengan adanya kejahatan dan kejahatan itu sendiri semakin lama semakin berkembang dan bervariasi. Selain 
itu pemikiran dan pembahasan tentang korban kejahatan semakin berkembang mengikuti perkembangan kejahatan bahkan pembahasannya semakin luas sampai ke masalah-masalah politik, sosial, ekonomi bahkan sampai pada masalah hak asasi manusia seperti yang dikemukakan oleh Mardjono Reksodiputro (J.E. Sahetapy, 1987 : 96).

Sementara itu kepentingan korban tindak pidana telah diwakili oleh alat negara yakni polisi dan jaksa sebagai penyelidik, penyidik, penuntut umum, akan tetapi hubungan antara korban tindak pidana di satu pihak dengan polisi dan jaksa di pihak lain adalah bersifat simbolik, sementara itu hubungan antara terdakwa dengan penasehat hukumnya secara prinsip adalah murni dalam hubungan hukum antara pengguna jasa dan pemberi jasa yang di atur dalam hukum perdata. Polisi dan jaksa bertindak untuk melaksanakan tugas negara sebagai wakil korban tindak pidana dan atau masyarakat, sedangkan penasehat hukum bertindak atas kuasa langsung dari terdakwa yang bertindak mewakili terdakwa sendiri. Singkatnya, pihak korban dalam sistem peradilan ini hanya dimanfaatkan untuk kepentingan pihak penguasa dalam rangka menegakkan hukum, sehingga pada hakekatnya, pihak korban dan pihak-pihak lain yang terlibat dalam pelaksanaan peradilan pidana tidaklah menegakkan hukum secara sempurna.

Pentingnya korban kejahatan memperoleh perhatian adalah berangkat dari pemikiran bahwa korban adalah merupakan pihak yang dirugikan dalam hal terjadinya suatu kejahatan, sehingga seyogyanya harus mendapat perhatian dan pelayanan dalam rangka memberikan perlindungan terhadap kepentingannya si korban. Di samping itu, seringkali korban memiliki peranan yang sangat penting bagi terjadinya suatu kejahatan, yang diharapkan dengan diperolehnya pemahaman yang luas dan mendalam tentang korban kejahatan akan dapat memudahkan dalam menemukan upaya penanggulangan kejahatan yang pada akhirnya akan bermuara pada keadilan dan menurunnya kuantitas ataupun kualitas dari kejahatan (Dikdik M. Arief Mansur dan Elisatris Gultom, 2006 : 29). Masalah kepentingan korban dari sejak lama kurang begitu mendapat perhatian, tetapi obyek perhatian ternyata masih lebih terfokus kepada bagaimana memberikan hukuman kepada si pelaku tindak pidana, dan hal itu masih melekat pada fenomena pembalasan belaka. Oleh karena itu menurut penulis, perlu dipaparkan tentang bagaimana kedudukan korban kejahatan dalam sistem peradilan pidana di Indonesia, mengingat bahwa peran korban dalam sistem peradilan pidana belum dapat di peran aktifkan dalam proses penyelesaian perkara pidana di Indonesia.

\section{Metode Penelitian}

Metode penelitian yang digunakan dalam penulisan karya ilmiah ini adalah penelitian hukum normatif, dengan menggunakan pendekatan undang-undang (act approach). Pendekatan undangundang (statue approach) dilakukan 
dengan menelaah semua undangundang dan regulasi yang bersangkut paut dengan isu hukum yang sedang ditangani (Peter Mahmud Marzuki, 2010 : 93).

\section{Pembahasan}

\section{Tinjauan Umum tentang Sistem Peradilan Pidana dan Korban Kejahatan}

Sistem Peradilan Pidana yang merupakan terjemahan dari Criminal Justice System secara singkat dapat diartikan sebagai suatu sistem dalam masyarakat untuk menanggulangi kejahatan agar hal tersebut masih berada dalam batas-batas toleransi masyarakat. Gambaran ini hanyalah salah satu dari tujuan sistem peradilan pidana yang ada secara universal, sehingga cakupan tugas sistem peradilan pidana itu memang dapat dikatakan luas, yaitu (dalam Mardjono Reksodiputro, 1994 : 85) :

1. Mencegah masyarakat menjadi korban kejahatan;

2. Menyelesaikan kejahatan yang terjadi sehingga masyarakat menjadi puas bahwa keadilan telah ditegakkan dan pelaku kejahatan telah dipidana; dan

3. Berusaha agar mereka yang pernah melakukan kejahatan itu tidak mengulangi perbuatannya lagi.

Sebagai suatu sistem, sistem peradilan pidana mempunyai komponen-komponen

penyelenggara, antara lain Kepolisian, Kejaksaan, Pengadilan dan Lembaga Pemasyarakatan yang semuanya saling terkait dan diharapkan adanya suatu kerjasama yang terintegrasi. Jika terdapat kelemahan pada salah satu sistem kerja komponennya, akan mempengaruhi komponen lainnya dalam sistem yang terintegrasi itu (Mien Rukmini, 2003 : 77). Sistem peradilan pidana dapat dilihat dari berbagai perspektif, antara lain Polisi, Jaksa, Hakim, tersangka/terdakwa dan korban kejahatan. Di antara persfektif tersebut, perspektif korban kejahatan akan membawa pada kecerahan sekaligus sebagai penyempurna dari persepektif lainnya yang dijadikan acuan dalam penyelenggaraan peradilan pidana sekarang ini.

Peradilan pidana selama ini lebih mengutamakan perlindungan kepentingan pembuat/pelaku kejahatan (offender centered), dilatarbelakangi oleh pandangan bahwa sistem peradilan pidana diselenggarakan untuk mengadili tersangka dan bukan untuk melayani kepentingan korban kejahatan, dengan alasan: kejahatan adalah melanggar kepentingan publik (hukum publik), maka reaksi terhadap kejahatan menjadi monopoli negara sebagai representasi publik atau masyarakat. Pandangan tersebut mendominasi praktik peradilan pidana, akibatnya orang yang terlanggar haknya dan menderita akibat kejahatan diabaikan oleh sistem peradilan pidana.

Melihat dalam sistem peradilan pidana, yang dibutuhkan untuk penegakan dalam suatu kejahatan atau tindak pidana adalah suatu sistem terpadu yang menunjukkan proses keterkaitan antar instansi atau pihak yang berwenang dalam menangani setiap kasus kejahatan. Selain itu diperlukan juga asas pelayanan yang mudah dan terjangkau bagi 
korban dalam setiap proses peradilan yang bertitik tekan pada perspektif korban yang mensyaratkan korban menjadi atau diletakkan pada pusat berjalannya sistem peradilan. Sebagai subyek, korban berhak didengar keterangannya, mendapat informasi atas upaya-upaya hukum yang berjalan, serta dipertimbangkan rasa keadilan yang ingin diperolehnya dan dipulihkan situasi dirinya atas perampasan hak-hak dan kerugian yang dialaminya.

Menurut

Mardjono

Reksodiputro, ada 4 (empat) pengertian korban yaitu (J.E. Sahetapy, 1987 : 96-97) :

a. Korban kejahatan konvensional seperti pembunuhan, perkosaan, penganiayaan, pencurian;

b. Korban kejahatan non konvensional seperti terorisme, pembajakan, perdagangan narkotika secara tidak sah, kejahatan terorganisasi dan kejahatan melalui komputer;

c. Korban penyalahgunaan secara melawan hukum kekuasaan ekonomi (illegal abuses of economic power) seperti pelanggaran terhadap peraturan perburuhan, penipuan konsumen, pelanggaran terhadap peraturan lingkungan, penyelewengan di bidang pemasaran dan perdagangan oleh perusahaan-perusahaan trans-nasional, pelanggaran peraturan devisa, pelanggaran peraturan pajak dan lain sebagainya;

d. Korban penyalahgunaan secara melawan hukum kekuasaan umum (illegal abuses of public power) seperti pelanggaran terhadap hak asasi manusia, penyalahgunaan wewenang oleh alat penguasa, termasuk penangkapan serta penahanan yang melanggar hukum dan lain sebagainya.

Pengertian korban dari sudut pandang yang sempit yaitu hanya terbatas pada korban kejahatan saja yaitu sebagai seorang yang telah menderita kerugian sebagai akibat suatu kejahatan dan atau yang rasa keadilannya secara langsung telah terganggu sebagai akibat pengalamannya menjadi target (sasaran) kejahatan (a victim is a person who has suffered damage as a result of a crime and or whose sense of justice has been directly disturbed by the experience of having been the target of a crime) (Muladi dan Barda Nawawi Arief, 1984 : 78). Menurut Undang-Undang Nomor 27 Tahun 2004 tentang Komisi Kebenaran dan Rekonsiliasi, yang dimaksud dengan korban adalah "orang perseorangan atau kelompok orang yang mengalami penderitaan, baik fisik, mental maupun emosional, kerugian ekonomi, atau mengalami pengabaian, pengurangan, atau perampasan hak-hak dasarnya sebagai akibat pelanggaran hak asasi manusia yang berat termasuk korban atau ahli warisnya." Sedangkan menurut Pasal 1 angka 2 Undang-Undang Nomor 13 Tahun 2006 tentang Perlindungan Saksi dan Korban, korban adalah seseorang yang mengalami penderitaan fisik, mental, dan/atau kerugian ekonomi yang diakibatkan oleh suatu tindak pidana.

\section{Kedudukan Korban Kejahatan dalam Sistem Peradilan Pidana Indonesia berdasarkan KUHAP}


Sistem peradilan pidana sekarang ini berlaku terlalu difokuskan pada pelaku dan kurang memperhatikan korban. Hal yang sering terjadi adalah terlibatnya korban dalam sistem peradilan pidana hanya menambah trauma dan meningkatkan rasa ketidak berdayaannya serta frustasi karena tidak diberikan perlindungan dan upaya hukum yang cukup. Sistem peradilan pidana dewasa ini memang terlalu "offender centered", sehingga mengharuskan kita untuk memperbaiki posisi korban dalam sistem ini agar apa yang diperolehnya tidak hanya kepuasan simbolik (Mardjono Reksodiputro, 1994: 81).

Korban kejahatan yang pada dasarnya merupakan pihak yang paling menderita dalam suatu tindak pidana, karena tidak memperoleh perlindungan sebanyak yang diberikan oleh undang-undang kepada pelaku kejahatan. Akibatnya, pada saat pelaku kejahatan telah dijatuhi sanksi pidana oleh pengadilan, kondisi korban kejahatan seperti tidak dipedulikan sama sekali. Padahal, masalah keadilan dan penghormatan hak asasi manusia tidak hanya berlaku terhadap pelaku kejahatan saja tetapi juga korban kejahatan. Dalam setiap penanganan perkara pidana aparat penegak hukum (polisi, jaksa) seringkali diperhadapkan pada kewajiban untuk melindungi dua kepentingan yang terkesan saling berlawanan, yaitu kepentingan korban yang harus dilindungi untuk memulihkan penderitaannya karena telah menjadi korban kejahatan (secara mental, fisik, maupun material), dan kepentingan tertuduh/tersangka sekalipun dia bersalah tetapi dia tetap sebagai manusia yang memiliki hak asasi yang tidak boleh dilanggar $(\mathrm{H}$. Parman Soeparman, 2007 : 63).

Dalam penyelesaian perkara pidana, seringkali hukum terlalu mengedepankan hak-hak tersangka atau terdakwa dan sementara hakhak korban diabaikan. Sebagaimana dikemukakan oleh Andi Hamzah, dalam membahas hukum acara pidana khususnya yang berkaitan dengan hak-hak asasi manusia, ada kecenderungan untuk mengupas hal-hal yang berkaitan dengan hakhak tersangka tanpa memperhatikan pula hak-hak para korban (Andi Hamzah, 1986 : 33).

Asas-asas hukum acara pidana yang dianut oleh KUHAP pun hampir semua mengedepankan hakhak tersangka. Paling tidak terdapat sepuluh asas yang dianut oleh KUHAP dengan maksud untuk melindungi hak warga negara dalam proses hukum yang adil (Romli Atmasasmita, 1996 : 41) yaitu:

1. Perlakuan yang sama di muka hukum tanpa diskriminasi apapun;

2. Praduga tidak bersalah;

3. Pelanggaran atas hak-hak individu warganegara (yaitu dalam hal penangkapan, penahanan, pengeledahan, dan penyitaan) harus didasarkan pada undangundang dan dilakukan dengan surat perintah;

4. Seorang tersangka hendaknya diberitahu tentang persangkaan dan pendakwaan terhadapnya;

5. Seorang tersangka dan terdakwa berhak mendapat bantuan penasihat hukum; 
6. Seorang terdakwa berhak hadir di muka pengadilan;

7. Adanya peradilan yang bebas dan dilakukan dengan cepat serta sederhana;

8. Peradilan harus terbuka untuk umum;

9. Tersangka maupun terdakwa berhak memperoleh kompensasi (ganti rugi) dan rehabilitasi; serta

10. Adalah kewajiban pengadilan untuk mengendalikan pelaksanaan putusanputusannya.

Melihat sepuluh asas di atas, secara normatif KUHAP hanya memperhatikan hak-hak pelaku kejahatan, tanpa memberi ruang kepada korban untuk memperjuangkan hak-haknya. Jika kita mencatat hak-hak korban yang ada dalam KUHAP, maka terdapat hanya 4 (empat) aspek, yaitu (dalam Mudzakir, 2001 : 76-77) :

1. Hak untuk melakukan kontrol terhadap tindakan penyidik dan penuntut umum, yakni hak mengajukan keberatan atas tindakan penghentian penyidikan dan/atau penuntutan dalam kapasitasnya sebagai pihak ketiga yang berkepentingan. Ini di atur dalam Pasal 109 dan Pasal 140 ayat (2) KUHAP;

2. Hak korban dalam kedudukannya sebagai saksi, sebagaimana di jumpai dalam Pasal 168 KUHAP;

3. Hak bagi keluarga korban dalam hal korban meninggal dunia, untuk mengijinkan atau tidak atas tindakan polisi melakukan bedah mayat atau penggalian kubur untuk otopsi. Hak demikian di atur dalam Pasal 134 sampai 136 KUHAP;
4. Hak menuntut ganti rugi atas kerugan yang di derita dari akibat tindak pidana dalam kapasitasnya sebagai pihak yang dirugikan. Dapat dijumpai dalam Pasal 98 sampai dengan Pasal 101 KUHAP.

Pasal 98-101 KUHAP adalah pasal-pasal yang berkaitan dengan hak korban dalam menuntut ganti kerugian. Mekanisme yang ditempuh adalah penggabungan perkara gugatan ganti kerugian pada perkara pidana. Penggabungan perkara ganti kerugian merupakan acara yang khas, yang ada di dalam isi ketentuan dari KUHAP.

Asas penggabungan perkara ganti kerugian pada perkara pidana dapat disebutkan sebagai berikut (R. Soeparmono, 2003 : 86) :

1. Merupakan praktek penegakan hukum berdasarkan ciptaan KUHAP sendiri bagi proses beracara (pidana dan perdata) untuk peradilan di Indonesia. KUHAP memberi prosedur hukum bagi seorang korban (atau bebarapa korban) tindak pidana, untuk menggugat ganti rugi yang bercorak perdata terhadap terdakwa bersamaan dengan pemeriksaan perkara pidana yang sedang berlangsung;

2. Penggabungan pemeriksaan dan putusan gugatan ganti kerugian pada perkara pidana sekaligus adalah sesuai dengan asas keseimbangan yang dimaksud KUHAP.

Maksud dari penggabungan perkara gugatan ganti kerugian adalah: pertama, agar perkara gugatan tersebut pada suatu ketika yang sama diperiksa serta diputus sekaligus dengan perkara pidana 
yang bersangkutan. Kedua, hal penggabungan sesuai dengan asas beracara dengan cepat, sederhana dan biaya ringan. Ketiga, orang lain termasuk korban, dapat sesegera mungkin memperoleh ganti ruginya tanpa harus melalui prosedur perkara perdata biasa yang dapat memakan waktu yang lama (R. Soeparmono, 2003 : 87).

Namun demikian, untuk dapat mengajukan penggabungan perkara gugatan ganti kerugian harus memperhatikan syarat-syarat sebagai berikut:

1. Harus berupa dan merupakan kerugian yang dialami oleh orang lain termasuk korban (saksi korban) sebagai akibat langsung dari tindak pidana yang dilakukan terdakwa;

2. Jumlah besarnya ganti kerugian yang dapat diminta hanya terbatas sebesar jumlah kerugian material yang diderita orang lain, termasuk korban tersebut;

3. Bahwa sasaran subjek hukumnya pihak-pihak adalah terdakwa;

4. Penuntutan ganti kerugian yang digabungkan pada perkara pidananya tersebut hanya dapat diajukan selambat-lambatnya sebelum penuntut umum mengajukan tuntutan pidana (requisitor);

5. Dalam hal Pentuntut Umum tidak hadir, tuntutan diajukan selambat-lambatnya sebelum Hakim menjatuhkan putusan.

6. Perkara pidananya tersebut menimbulkan kerugian bagi orang lain. Kerugian bagi orang lain termasuk kerugian pada korban;
7. Penuntutan gugatan ganti kerugian yang digabungkan pada perkara pidana tersebut tidak perlu diajukan melalui Panitera Pengadilan Negeri, melainkan dapat langsung diajukan dalam sidang Pengadilan melalui Majelis Hakim / Hakim;

8. Gugatan ganti kerugian Pasal 98 ayat (1) KUHAP adalah, harus sebagai akibat kerugian yang timbul karena perbuatan terdakwa dan tidak mengenai kerugian-kerugian lainnya.

Dari uraian di atas, maka dapat diketahui, yang dapat diajukan dalam penggabungan perkara gugatan ganti kerugian hanya terbatas pada tuntutan ganti kerugian yang secara nyata-nyata (riil) dikeluarkan, atau dengan kata lain ganti kerugian material. Pembatasan ini dimaksudkan didasarkan pada (dalam R. Soeparmono, 2003 : 88-89) :

a. Proses penggabungan perkara gugatan ganti kerugian tersebut harus berjalan cepat, tidak memakan waktu yang lama dan seketika dan segera mungkin dapat direalisasikan, serta adanya prinsip pemeriksaan peradilan yang cepat dan sederhana. Misalnya, hanya membuktikan bukti-bukti surat dan kwitansi, biaya pengobatan, biaya perawatan, biaya memperbaiki kendaraan, dll;

b. Kerugian materiil yang berupa kerugian yang secara nyata (riil) tersebut mudah pembuktiannya;

c. Karena hanyalah kerugian yang immaterial tidak dapat diterima untuk penggabungan perkara gugatan ganti kerugian; 
d. Karena itulah, imbalan ganti kerugian immateriil harus dipisahkan, dengan maksud agar diajukan tersendiri pada gugatan perdata biasa, karena dipandang tidak sederhana dan tidak mudah;

e. Karena pemeriksaan dan pembuktiannya yang sulit serta memakan waktu, dan juga menghambat pemeriksaan pidananya, sehingga bertentangan dengan asas peradilan yang sederhana, cepat dan biaya ringan.

Dengan adanya pembatasan di atas, muncul kelemahan-kelamahan dari praktek penggabungan gugatan ganti kerugian yang ada dalam KUHAP, diantaranya:

a. Sistem penggabungan tersebut dirasakan belum mendekati hakekat tujuan ganti kerugian itu sendiri;

b. Tuntutan ganti kerugian oleh orang lain yang menderita langsung kerugian atau pihak korban untuk memperoleh jumlah besarnya ganti kerugian dibatasi hanya kerugian materiil yang nyata-nyata dikeluarkan oleh orang yang dirugikan langsung tersebut. Jadi KUHAP dalam ketentuanketentuannya membatasi hak;

c. Untuk kerugian non materiil, yaitu kerugian immateriil terpaksa harus mengajukan lagi dengan gugatan perdata biasa tersendiri, yang mungkin dapat memakan waktu lama;

d. Kondisi seperti ini berarti mengaburkan maksud semula dari penggbungan itu sendiri, yang bertujuan untuk menyederhanakan proses; e. Adanya kendala dalam pelaksanaan masalah pembayaran ganti kerugian tersebut;

f. Apabila pihak korban tetap menuntut ganti kerugian yang bersifat immateriil juga, hasilnya akan nihil, karena putusan selalu menyatakan: gugatan ganti kerugian immateriil tersebut dinyatakan tidak dapat diterima, karena tidak berdasarkan hukum;

g. Majelis hakim / hakim harus cermat, sebab selalu harus memisahkan antara kerugian materiil dengan kerugian immateriil, sehingga tidak efisien;

h. Karena gugatan ganti kerugian pada perkara pidana hanya bersifat assessor;

i. Pada setiap putusan perdatanya, pihak korban/penggugat dalam penggabungan perkara gugatan ganti kerugian tersebut selalu menggantungkan pihak terdakwa atau Jaksa Penuntut Umum jika mau banding, sehingga melenyapkan hak banding sebagai upaya hukum.

Kelemahan-kelemahan di atas semakin mempersempit ruang korban tindak pidana untuk mengajukan hak-haknya, penggabungan gugatan ganti kerugian hanya memberikan peluang untuk kerugian materiil saja, sedangkan untuk pemulihan kerugian immateriil masih harus diajukan secara terpisah melalui gugatan perdata yang pada prakteknya tidak sederhana.

Apabila kita cermati mengenai hak-hak korban yang tertuang di dalam KUHAP, maka di 
dapat pengaturan hak-hak bagi korban sangat minim sekali dibandingkan dengan pengaturan tentang hak-hak pelaku tindak pidana (tersangka / terdakwa / terpidana). Perlindungan hukum lebih banyak di atur untuk pelaku tindak pidana, sebagaimana tampak dalam berbagai Pasal tersebut di atas dibandingkan dengan kepentingan korban yang mengalami penderitaan dari perbuatan pelaku tindak pidana.

Eksistensi dan posisi hukum korban tindak pidana dalam sistem peradilan pidana, tidak menguntungkan bagi korban tindak pidana, karena terbentur dalam permasalahan yang mendasar yakni korban hanya sebagai saksi (pelapor atau korban). Korban tidak termasuk dalam bagian dari unsur yang terlibat dalam sistem peradilan pidana, tidak sebagaimana terdakwa, polisi, jaksa, hakim. Hal tersebut berakibat bagi korban tindak pidana tidak mempunyai upaya hukum, apabila ia keberatan terhadap suatu putusan pengadilan, misalnya banding atau kasasi apabila putusan pengadilan yang di pandang tidak adil atau merugikan dirinya (Mudzakkir, 2001). Korban dari kejahatan tersebut, "dapat" hadir dalam proses peradilan pidana dengan 2 (dua) kualitas yang berbeda. Pertama, korban hadir sebagai saksi. Fungsi korban disini adalah memberi kesaksian dalam rangka pengungkapan kejahatan yang sedang dalam proses pemeriksaan, baik pada tahap penyidikan, tahap penuntutan maupun pada tahap pemeriksaan di sidang pengadilan. Kedua, korban hadir sebagai pihak yang dirugikan.
Fungsi korban dalam hal ini adalah mengajukan tuntutan ganti kerugian terhadap pelaku kejahatan yang telah mengakibatkan kerugian atau penderitaan pada dirinya (JE. Sahetapy, 1987 : 35). Uraian di atas menunjukan bahwa masalah kepentingan korban tindak pidana masih saja mendapat tantangan dari sudut mekanisme peradilan pidana, karena pembuat undang-undang (kebijakan legislatif) (Barda Nawawi Arif, 2001 : 75).

Selama ini pengaturan perlindungan korban khususnya dalam sistem peradilan pidana Indonesia belum menampakkan pola yang jelas. Menurut Barda Nawawi Arief dalam hukum pidana positif yang berlaku pada saat ini perlindungan korban lebih banyak merupakan "perlindungan abstrak" atau "perlindungan tidak langsung". Artinya berbagai rumusan tindak pidana dalam peraturan perundangundangan selama ini pada hakekatnya telah ada perlindungan in abstracto secara langsung terhadap kepentingan hukum dan hak asasi korban. Dikatakan demikian, karena tindak pidana menurut hukum positif tidak dilihat sebagai perbuatan menyerang atau melanggar kepentingan hukum seseorang (korban) secara pribadi dan konkret, tetapi hanya dilihat sebagai pelanggaran "norma atau tertib hukum in abstracto". Akibatnya perlindungan korban tidak secara langsung dengan in concreto, tetapi hanya in abstracto (Muladi dan Barda Nawawi Arief, 1992 : 78). Dengan kata lain, sistem sanksi dan pertanggungjawaban pidananya tidak tertuju pada perlindungan korban secara langsung dan konkrit, tetapi hanya 
perlindungan korban secara tidak langsung dan abstrak. Jadi pertanggungjawaban pelaku bukanlah pertanggungjawaban terhadap kerugian atau penderitaan korban secara langsung dan konkrit, tetapi lebih tertuju pada pertanggungjawaban pribadi atau individual.

Pada dasarnya ada 2 (dua) model pemberdayaan korban dalam Sistem Peradilan Pidana, yaitu: Pertama, model hak-hak prosedural (the procedural rights model). Secara singkat, model ini menekankan dimungkinkan berperan aktifnya korban dalam proses peradilan pidana seperti membantu jaksa penuntut umum, dilibatkan dalam setiap tingkat pemeriksaan perkara, wajib didengar pendapatnya apabila terpidana dilepas bersyarat, dan lain sebagainya. Kedua, model pelayanan (the services model) yang menekankan pada pemberian ganti kerugian dalam bentuk kompensasi, restitusi dan upaya pengambilan kondisi korban yang mengalami trauma, rasa takut dan tertekan akibat kejahatan (Muladi dan Barda Nawawi Arief, 1992 : 81). Model pemberdayaan korban yang cocol diterapkan di Indonesia adalah model pelayaman karena ketiadaan hak korban ikut campur dalam sistem peradilan pidana, proses peradilan menjadi monopoli aparat hukum.

Korban bukan bagian yang terpisahkan dalam proses peradilan pidana. Kenyataannya perhatian terhadap korban sebelum era reformasi sangat kecil (minimal). Sesudah reformasi bermunculan perundang-undangan yang mengatur hak-hak dan perlindungan korban (Bambang Waluyo, 2011 : 22). Selain itu, legalitas perlindungan korban dan saksi telah tersurat dalam UndangUndang Nomor 13 Tahun 2006 tentang Perlindungan Saksi dan Korban, yang ditindaklanjuti dengan Peraturan Pemerintah Nomor 44 Tahun 2008 tentang Pemberian Kompensasi, Restitusi, dan Bantuan Kepada Saksi dan Korban. Namun yang lebih penting adalah aplikasi dan implementasinya. Untuk mewujudkan secara proporsional, professional dan akuntabel, diperlukan keseriusan dari para pihak.

\section{Simpulan}

Kedudukan korban dalam sistem peradilan pidana, tidak menguntungkan bagi korban tindak pidana, karena terbentur dalam problem yang mendasar yakni korban Korban kejahatan ditempatkan sebagai alat bukti yang memberi keterangan yaitu hanya sebagai saksi (168 KUHAP) sehingga kemungkinan untuk memperoleh keleluasaan dalam memperjuangkan haknya sangatlah kecil. Korban tidak termasuk dalam bagian dari unsur yang terlibat dalam sistem peradilan pidana, tidak sebagaimana terdakwa, polisi, jaksa, hakim. Pengaturan hak-hak korban yang tertuang di dalam KUHAP, maka di dapat pengaturan hak-hak bagi korban sangat minim sekali dibandingkan dengan pengaturan tentang hak-hak pelaku tindak pidana. Hak menuntut ganti rugi atas kerugian yang di derita dari akibat tindak pidana dalam kapasitasnya sebagai pihak yang dirugikan dapat dijumpai dalam Pasal 98 sampai dengan Pasal 101 
KUHAP, namun penggabungan gugatan ganti kerugian hanya memberikan peluang untuk kerugian materiil saja, sedangkan untuk pemulihan kerugian immateriil masih harus diajukan secara terpisah melalui gugatan perdata yang pada prakteknya tidak sederhana.

\section{Saran}

Melihat kedudukan korban yang tidak seimbang dengan

\section{Daftar Pustaka}

Arief, Barda Nawawi, 2001, Masalah Penegakan Hukum \& Kebijakan Penanggulangan Kejahatan, Citra Aditya Bakti, Bandung.

Arief, Dikdik M Mansur dan Elisatris Gultom, 2006, Urgensi Perlindungan Korban Kejahatan: Antara Norma dan Realita, Rajawali Pres, Jakarta.

Atmasasmita, Romli, 1996, Sistem Peradilan Pidana (Persepektif Ekistensialisme dan Abolisionisme), Binacipta, Bandung.

Hamzah, Andi, 1986, Perlindungan Hak-hak Asasi Manusia dalam Kitab Undang-undang Hukum Acara Pidana, Binacipta, Bandung.

Marzuki, Peter Mahmud, 2010, Penelitian Hukum, Kencana Prenada Media Group, Jakarta.

Mudzakir, 2001, "Posisi Hukum Korban Tindak Pidana Dalam Sistem Peradilan Pidana", Sahetapy, J.E., 1987, Viktimologi Sebuah Bunga Rampai, Pustaka Sinar Harapan, Jakarta.

Soeparmono, R., 2003, Praperadilan dan Penggabungan Perkara Gugatan Ganti Kerugian dalam kepentingan pelaku tindak pidana dalam sistem peradilan pidana yang tertuang di dalam sistem peradilan pidana, maka sudah saatnya dilakukan pembaharuan hukum pidana dalam KUHAP mengenai hak korban dalam sistem peradilan pidana agar hak-hak dan kepentingan korban tindak pidana berimbang dengan hak-hak pelaku tindak pidana.

Disertasi Program

Pascasarjana Fakultas Hukum Universitas Indonesia, Jakarta.

Muladi dan Barda Nawawi Arief, 1984, Teori- teori dan Kebijakan Pidana, Alumni Bandung. 1992, Bunga Rampai Hukum Pidana, Alumni, Bandung.

Reksodiputro, Mardjono, 1994, Hak Asasi Manusia dalam Sistem Peradilan Pidana, Pusat Pelayanan Keadilan dan Pengabdian Hukum Universitas Indonesia, Jakarta.. 1994, Kriminologi dan Sistem Peradilan Pidana, Buku II LKUI, Jakarta.

Rukmini, Mien, 2003, Perlindungan HAM Melalui Asas Praduga Tidak Bersalah dan Asas Persamaan Kedudukan dalam Hukum Pada Sistem Peradilan Pidana Indonesia, Alumni, Bandung.

KUHAP, Mandar Maju, Bandung.

Soeparman, H. Parman, 2007, Pengaturan Hak Mengajukan Upaya Hukum Peninjauan Kembali Dalam Perkara Pidana 
Bagi Korban Kejahatan, Refika Aditama, Bandung.

Waluyo, Bambang, 2011, Viktimologi Perlindungan Kitab Undang-Undang Hukum Acara Pidana (KUHAP).

Undang-Undang Nomor 27 Tahun 2004 tentang Komisi Kebenaran dan Rekonsiliasi.

Undang-Undang Nomor 13 Tahun 2006 tentang Perlindungan Saksi dan Korban.
Korban \& Saksi, Cet.pertama, Sinar Grafika, Jakarta. 